\title{
雌モルモットを用いたホルモン音声障害の基礎的研究
}

\author{
稲上憲一, 北原哲 \\ 小倉 雅實, 井上 鐵三
}

\section{Histopathological Study of the Larynx after Administration of Androgenic Hormone in Guinea Pig}

\author{
Ken-ichi Inakami, M.D., Satoshi Kitahara, M.D., \\ Masami Ogura, Ph.D., and Tetsuzo Inouye, M.D.
}

Department of Otolaryngology, National Defense Medical College, Saitama

Histopathological changes of the vocal cords after anabolic steroid administration have not been clearly resolved. In this study, histopathological changes in the larynx of anabolic steroid induced dysphonia are investigated.

The experimented animals were female guinea pigs at 4 weeks of age. Twenty guinea pigs received $50 \mathrm{mg}$ of testosterone enantate intramuscularly once a week. And another twenty were used for control study (free from hormone injection). Their voices were recorded and analysed weekly. After 5 or 6 weeks of administration of testosterone enantate, the voice became rough or breathy in all hormone group. The larynges of both groups were excised, sectioned and stained by $\mathrm{H}-\mathrm{E}$ and Azan. Observation of the vocal cords was made under the light microscope. The histopathological changes were as follows. 1) Cricoarytenoid muscle fibers were hypertrophied. 2) In lamina propria, the number of fibrobrasts increased. 3) The fibers showed irreguler alignment and their continuity was broken. 4) The space among collagenous fibers became narrow.

From these observations, it can be concluded that the larynx is one of the main targets for anabolic steroid and it is suggested that the dysphonia in due to the qualitative change in the lamina propria of the vocal cord and the hypertrophy of the cricoarytenoid muscle.

Key words : ホルモン音声障害, モルモット, testosterone, 声帯粘膜固有層

\section{I . 緒 言}

Testosteroneは男性ホルモン剤の一つであ

防衛医科大学校耳鼻咽喉科学講座 (主任: 井上鐵三 教授)

別刷請求： テ359 埼玉県所沢市並木3-2 防衛医科大学校耳鼻咽喉科学講座 稲上憲一

投稿受付：1990年 2 月23日
り, 骨髄線維症, 腎性貧血, 再生不良性賓血, 末期乳癌などの治療に用いられている。男性ホ ルモン（アンドロゲン）は，1. 雄性副性器発 育肥大作用, 2 . 第二次性徵出現促進作用, 3 . 性欲元進作用, 4. 造精作用, 5. 間脳性中枢 抑制作用, 6 . 蛋白同化作用などの諸種の生理 作用を有している。1〜 5 は雄性性機能に関す るものであり，6は性機能遂行に必要な基礎的 代謝づくりに関与している。 
アンドロゲン製剤の副作用として月経異常, アクネ, 口渴, 浮腫, 多毛などがあるが, ほか に声の高さや音質の変化といった音声障害も耳 鼻咽喉科領域ではよく知られていて, Goldman ら"は testosterone を筋注した女性400例中23 例に, 梅原 ${ }^{2}$ は673例の男女の内19例に音声障害 が認められたと述べている。これまでこの音声 障害に関しては諸家により発生頻度, 症状, 喉 頭の肉眼的所見などが報告されているが，音声 障害の出現率は, 思春期, 更年期の女性に頻度 が高いという報告3)と，その時期には関係なく 出現するという報告4)とがあり, 定説はなく, 個 人差が大きいというのが諸家の一致した意見で ある。

音声変化の特徵として Bauer $\left.{ }^{4}\right)$ は, 初期の症 状として自覚的な音声の易疲労性, その後に嗄 声, 話声位の低下, 声域の下方移動と表現し, Goldman ら ${ }^{11}$ は huskiness, 男性的な声, 岡村 ららはいわゆる声がれ, 大きな声が出ない, 低音 化，と報告している。

また喉頭所見についても，加藤 ${ }^{3}$ は女性で蛋 白同化ホルモンを投与された剖検例のヒト死体 喉頭を非投与例と比較し, 肉眼的に喉頭には差 が認められなかったと報告しているが，肉眼的 な変化が認められないという意見に対し, 認め られるという報告6もある。これには投与量, 観 察時期の差による違いが関与しているものと考 えられるが，いずれにせよ見解の一致を見てい ない。

過去におけるホルモン音声障害に関する実験 的研究は, Leonard ${ }^{7}$ が䧳のカナリアに男性ホル モンを注射し鳴き声の変化を観察したことに始

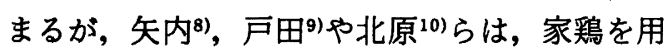
いてホルモン音声障害を作成している。加藤や Haubrich ら ${ }^{11}$ は, アンドロゲンホルモンを投 与したマウスにおける喉頭筋の筋線維の変化 を, 組織学的あるいは組織化学的変化として,

Sobel ら ${ }^{12}$ は結合組織に及ほすホルモンの影響 を生化学的に, 戸田9), 北原ら ${ }^{10)}$ は鳴膜の上皮や 粘膜固有層の変化を病理組織学的に報告してい る。

しかし実験的にも，マウスの喉頭や鳥の鳴管 の肉眼的変化は認められず, 病理組織学的な検 索として内喉頭筋の肥大が主な器質的変化とす
る報告と，上皮あるいは粘膜固有層にホルモン の影響があらわれるという報告が主なものと考 えられるが，これらによって音声障害の本態が 解明されているとは言いがたい。北原ら ${ }^{10)}$ は家 䳕を用いた実験結果から,「容易に鳴き声が得ら れる哺乳動物」を用いて, ホルモン音声障害の 本態を解明することが良策であると提案してい るが，われわれは偶然にもモルモットにおいて その鳴き声が容易に得られることを見いだし た。ここに実験動物として雌モルモットを用い, ホルモン音声障害を作成した後, その音声の分 析と声帯の病理組織学的観察を行い, この音声 障害の本態の解明を試みた。

\section{II. 方 法}

生後約 4 週目の体重200 250 g の雌モルモ ット（ハートレー）40匹を実験動物として用い た。うち20匹をホルモン投与群として週 1 回工 ナント酸テストステロン (エナルモンデポー ${ }^{\circledR}$ ) $50 \mathrm{mg}$ を大腿部に筋注, 同時に体重を測定し, 音 声を防音室にてテープレコーダーに録音した。 モルモットの音声は, 項部皮膚を把握して刺激 することにより容易に得られた。他の20匹はコ ントロール群として体重測定と音声記録のみを 同様に行った。 $5 \sim 6$ 週経過すると, テストス テロンを投与されたモルモットに聴覚的に明瞭 な気息性嗄声が出現した。

記録した音声のレコードテープを再生し, A$\mathrm{D}$ 変換の後コンピューターに入力, 音声波形の 抽出と周波数分析を行った。使用器械はカセッ トテープレコーダー, SONY TC-2500, パーソ ナルコンピューター, NEC PC-9801VX, 波形 観測ソフトウェア, カノープス社, DSS98 TYPE IVを用いた。

恥覚的に嗄声が出現した時点で，コントロー ル群とホルモン投与群とを同時に屍殺し, その 喉頭を摘出し $10 \%$ ホルマリン液で固定, パラフ イン包埋し, 標本を作製した。標本は水平断と 前額断で厚さ $3 \mu \mathrm{m}$ の連続切片とし, H-E およ びAzanにて染色した。

検索部位は声帯遊離縁部の上皮, 粘膜固有層, および甲状披裂筋としたが，さらに水平断で胸 骨舌骨筋, 前額断で甲状披裂筋の筋線維断面を 400倍の拡大写真にとり, その面積を Ushikata 
X-Plan 360i を使用して測定した。1つの標本 より 300 の筋線維を抽出し, その断面積の平均值 を求めて筋線維断面積とした。断面積の比較に あたって, 両群からはほほ同じ体重のものを選 んた゚。

\section{III. 結 果}

\section{1. 音声分析, 周波数分析}

ホルモン投与群は投与 6 週目までには程度に 差はあるものの, 全例聴覚的には気息性嗄声を 示した。図 1 はホルモン非投与モルモットの音 声波形と周波数分析を示しているが, その音声 波形は規則正しく周期性を保っていて, 振幅に も乱れのない波形を示し, 基本周波数は $2750 \mathrm{~Hz}$ で，正数倍にピークが明瞭にみられる。図 2 は 同じ日に記録したホルモン投与後 5 週目のモル
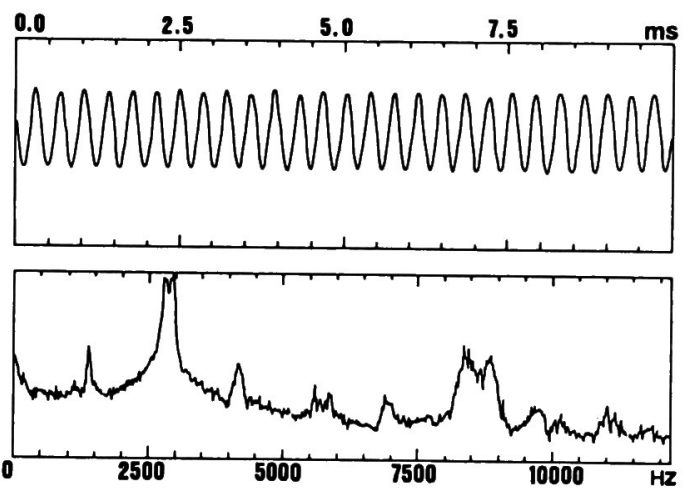

図 1 正常モルモットの音声波形および周波数分析
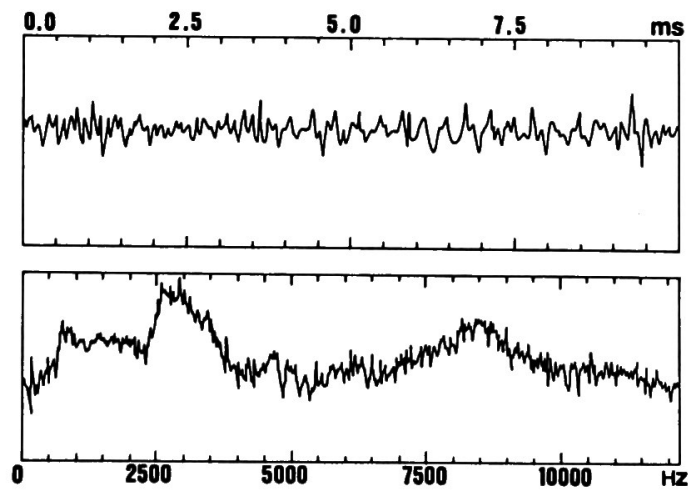

図2 男性ホルモン投与モルモットにおける音声波 形および周波数分析（気息性嗄声出現時）
モットの波形を示しているが，音声波形は先の ような規則正しい波形をとらず不規則である。 またその周波数分析では周波数帯域の分散がみ られ, 基本周波数は不明瞭となっている。

\section{2. 病理組織学的变化}

モルモットの声帯は, はっきりした褺を呈し ておらず喉頭室もない。声帯は甲状披裂筋部に あり，その上皮は遊離縁部が重層扁平上皮とな っている(図 3)。声帯の上下面は多列線毛上皮 と,腺組織を含んだ粘膜固有層を形成している。 声帯粘膜固有層は大部分膠原線維で形成され, 前後方向に線維が並んでいる。毛細血管は上皮 下に多く, 特に声帯後部に多い。弾性線維は声 門下粘膜固有層の深層および浅層に分布してい るが, 頭側にゆくに従い減少し, 声帯遊離縁部 でほとんど消失している。図 4 にコントロール 群の声帯遊離縁部の水平断を示す。粘膜固有層 の線維の走行は一定であり,その連続性を保っ ている。また浅層と深層には弾性線維の層がみ られる。

図 5 はホルモン投与群で嗄声のあるモルモッ

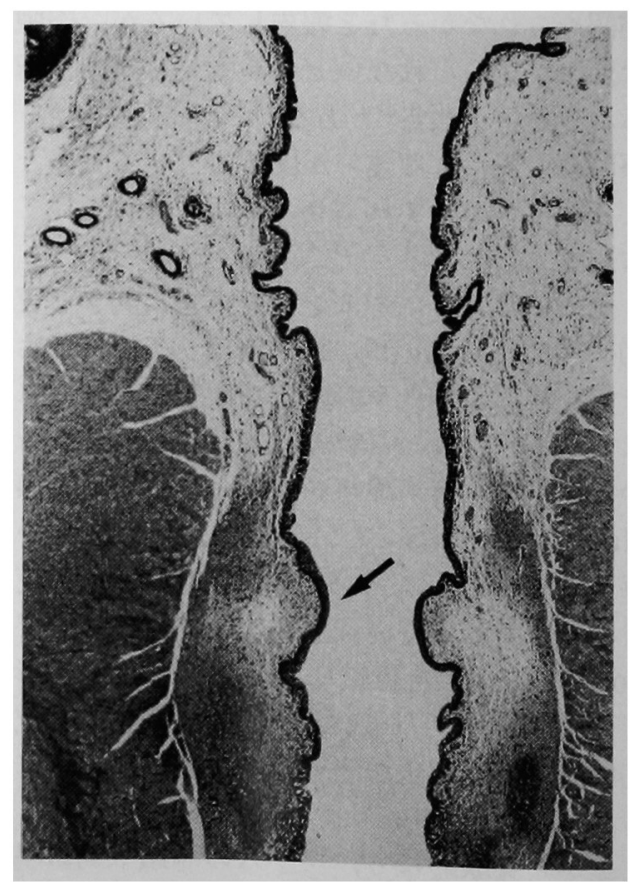

図 3 正常モルモットの喉頭前額断 矢印: 声帯遊離縁部, H-E 染色, $\times 40$ 。 


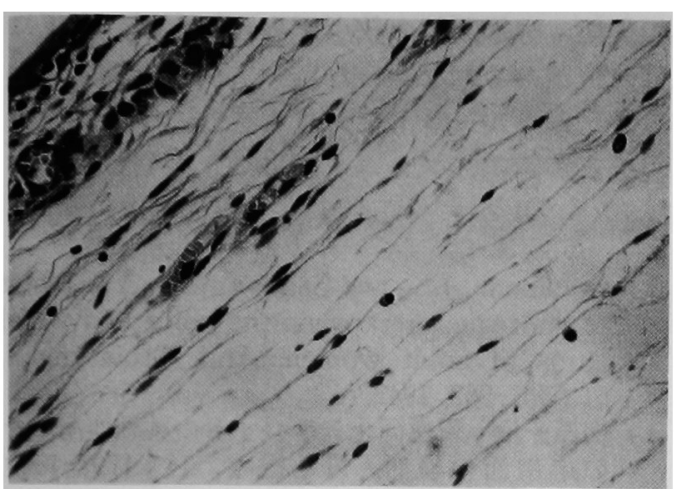

图4 正常モルモットの声帯遊離縁部水平断, 上皮 および粘膜固有層を示す

H-E 染色, $\times 200$ 。

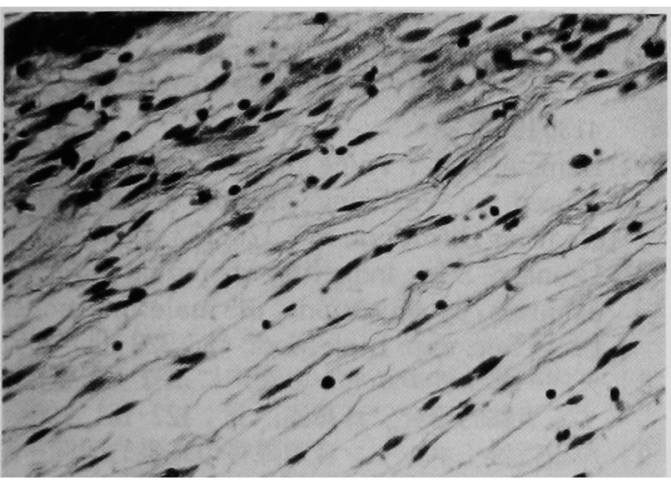

図 5 男性ホルモン投与モルモット嗄声出現時の声 帯遊離緑部水平断の上皮および粘膜固有層を 示す

線維の走行の乱れ, fibroblast の増加と線維間の狭 小が見られる。H-E 染色, $\times 200$ 。

トの声帯遊離緑部水平断を示す。粘膜固有層は 膠原線維の走行に乱れを生じ, 線維間の間隔も 狭く連続性に欠けている。また fibroblast cell は増加している。上皮および弾性線維の変化は 明確ではない。

\section{3. 筋線維断面皘}

甲状披裂筋と胸骨舌骨筋の筋線維断面積の比 較において，甲状披裂筋ではホルモン非投与モ ルモットの平均筋線維断面積は $0.30 \mathrm{~nm}^{2}$, ホル モン投与モルモットのそれは $0.43 \mathrm{~nm}^{2}$ 。胸骨舌 骨筋では非投与モルモット $1.13 \mathrm{~nm}^{2}$, ホルモン 投与モルモット $1.55 \mathrm{~nm}^{2}$ であり, 両者ともホル
モン投与群に筋線維の肥大がみられ, $\mathrm{t}$ 検定に て危険率 $5 \%$ で有意差があった。

\section{IV. 考 察}

アンドロゲン感受性組織である精囊と前立腺 は, testosterone と $5 \alpha$-dihydrotestosterone （DHT）に対して親和性の強い結合蛋白をもっ ている。これらのレセプターをもった蛋白は, アンドロゲン作用を標的細胞に伝える中間体と なり，加えて骨格筋にも同化作用を及ほす。こ れはラット，モルモットの肛門筋や，ラットの 大腿筋, 広筋, 膀胱筋, 広背筋, 横隔膜で確加 められている。

Lieberburg と Nottebohm ${ }^{13)}$ は Zebra finches を使い, 鳥の声帯に当たるSyrinx の筋 肉内の testosterone receptor 調べ, Syrinx 以外の横紋筋にみられる以上の receptor が存 在することを報告し，またSaez $ら^{14)} /{ }^{3} \mathrm{H}$ DHTで incubate した喉頭および咽頭の粘膜 細胞のアンドロゲン結合蛋白の量を測定するこ とにより, 男性の喉頭, 咽頭粘膜にアンドロゲ ン receptor が存在することを示し, 女性におい てもDHT の標的細胞となる粘膜があることか ら，アンドロゲンの投与で音声変化をきたす可 能性を示している。

このように，横紋筋の結合部位は本来のアン ドロゲンの標的組織と比較すると数は少ない が，このホルモンの同化作用が発声に及ぼす影 響は確かである。平野ら ${ }^{15)}$ は, 声帯筋とその他の 内喉頭筋の収縮運動と, 上皮および粘膜固有層 の波動運動によって声帯振動が成り立っている と述べているが，ホルモン音声障害のメカニズ ムに対し加藤ら ${ }^{3)}$ は, 声帯筋線維の不規則な肥 大傾向の存在のため他筋群との共同運動に乱れ を生じ, 筋緊張の変動がバランスをくずし機能 不全を来すと考察している。

一方戸田9は，雌家鵎に男性ホルモンを投与 することによって音声障害を作成し，鼓状膜に おける粘膜上皮の肥厚, 粘膜固有層の線維の走 行の乱れという病理組織学的所見より雌家鶏の ホルモン音声障害は鼓状膜の粘弾性の低下によ るものであろうと述べ，上皮および粘膜固有層 がより大きく関与しているとしている。

しかし Talaat ら ${ }^{16)} は$, anabolic steroid を投 
与した albino マウスの声帯の組織学的考察を 行い, 上皮には parakeratosis と扁平上皮化生 が起こり, 甲状披裂筋には肥大と筋線維の太さ の乱れが生じたとしたが, 音声の変化は上皮の 変化よりも筋の肥大によるところが大きいとし ている。

われわれの実験では，男性ホルモン投与によ り音声障害をきたしたモルモットにおいて，甲 状披裂筋および胸骨舌骨筋の肥大が認められた が，筋線維の断面積の分布はほほ正規分布をと り，その太さに乱れは認められなかったこと， 粘膜固有層には明らかに器質的変化が現れてい たこと, 音声障害は気息性嗄声として現れたこ となどから考察してみると, 音声に及ほす声帯 筋肥大の意義よりも, 声帯の粘膜固有層の線維 の乱れゃ, fibrobrast の増生に起因する物理学 的性状の変化の方が疾患の本質により近いので はないかと考えられる。

北原ら ${ }^{10)}$ は, 雌家鶏に男性ホルモンを投与し, 音声障害を作成した上でエストロゲン，プロゲ ステロンの併用投与を行ったところ, 著明な改 善がみられ，音声分析では正常と区別ができな かったと述べている。家鷄の鳴管には筋組織を 欠くという点, また Holt ら ${ }^{17) や ~ A u f d e m o r t e ~}$ ら ${ }^{18)}$ のオートラジオグラフィーで投与したヒヒ の声帯上皮および粘膜固有層に, testosterone の集積がみられていること等あわせて考えてみ ると, 男性ホルモン投与による音声障害が筋肉 の肥大という変化より, 粘膜固有層の物理学的 性状の変化の方がより大きく関与しているので はないかという印象を受ける。

\section{V.まとめ}

1) 雌モルモットに男性ホルモンを投与し, 音声障害を作成し, その声帯遊離緑部の病理組 織学的変化を観察した。

2) 雌モルモットにエナント酸テストステロ ン $50 \mathrm{mg}$ を毎週 1 回投与すると, $5 \sim 6$ 週で音 声障害 (気息性嗄声) を生じた。

3 ） ホルモン投与群の甲状披裂筋および胸骨 舌骨筋は, コントロール群に比べて有意にその 筋線維が肥大していた。

4 ) 病理組織学的にはホルモン投与群の粘膜 固有層の fibrobrast の増生と膠原線維の連続性
の欠如，線維間隙の狭小がみられたが，上皮に は変化がみられなかった。

5 ) 雌モルモットにおける男性ホルモン投与 後の音声障害のメカニスムにつき考察した。

\section{文 献}

1) Goldmann, J.L., and Salmon, U.J. : The effect of androgen therapy on the voice and vocal cords of adult women. Ann. Otolaryngol., $51: 961-963,1942$.

2 ）梅原千治：蛋白同化ステロイドの薬理作用とそ の応用面の検討. 最新医学, $17: 1791-1809$, 1962.

3 ）加藤友康：蛋白同化ステロイドによる音声障害 の研究. 日鼻耳, $76: 1073-1094,1973$.

4) Bauer, H.: The influence of the androgenic hormones on the female voice. International Association of Logopedics and Phonatrics XIIth Congress Abstracts, 10, 1962.

5 ) 岡村正美, 沢島政行, 廣瀬 肇-他：蛋白同化 ステロイド使用による音声障害. 耳喉, $36: 409$ 413, 1964.

6) Damsté, P.H. : Voice change in adult women caused by virilizing agents. J. Speech \& Hearing Disorders, $32: 126-132,1967$.

7 ) Leonard, S.L. : Induction of singing in female canaries by injections of male hormones. Prog. Soc. exp. Biol. Med., 41:229-230, 1961.

8 ) 矢内一郎：性ホルモンの音声に及ほす影響に関 する実験的研究。耳鼻臨, 36：122-161, 1961.

9 ) 戸田行雄：ホルモン音声障害の基礎的研究一家 鷄における発声器の器質的変化について一. 耳 鼻, 29:70-94, 1983.

10）北原 哲, 井上鐵三, 戸田行雄・他：雌家鷄を 用いたホルモン音声障害の基礎的研究.耳鼻, $31: 931-938,1985$.

11) Haubrich, J., Schätzle, W., and Stennert, E. : Histologische und histochemische Untersuchungen zur Frage der Reversibilität von Kehlkopf veränderungen bei der weiblichen Maus nach Androgenbehandlung. Zeitschrift für L.R.O., 49 : 168-175, 1970.

12) Sobel, H., and Marmorston, J.: Hormonal influences upon connective tissue changes of aging. Recent. Prog. Hormone Res., 14 : 457481, 1958.

13) Lieberburg, I., and Nottebohm, F.: Highaffinity androgen binding proteins in syringeal tissues of songbirds. Gen. Comp. Endocrinol., $37: 286-293,1979$.

14) Saez, S., Martin, P.M., and Gigroux, B.: Androgen receptors in larynx and pharynx. "Normal and Epitheliomatous. : Steroid Receptors and Hormone Dependent Neoplasia, T. 
C. Whitliff, O. Dapunt, and N.Y. Masson, (Eds.), pp.205-208, 1978.

15）平野 実, 小池祐一, 広瀬幸矢・他：振動体と しての声帯の構造. 日耳鼻, $76: 1341-1350$, 1976.

16) Talaat, M., Talaat, A.M., Kelada, I., et al. : Histologic and histochemical study of effects of anabolic steroids on the female larynx. Ann. Otol. Rhinol. Laryngol., 96:468-471,
1987.

17) Holt, G.R., Aufdemorte, T.B., and Sheridan, P.J.: Estrogen receptor in the larynx of the aged baboon. Ann. Otol. Rhinol. Laryngol., 95:608-617, 1986.

18) Aufdemorte, T.B., Sheridan, P.J., Holt, G.R., et al. : Autoradiographic evidence of sex steroid receptors in laryngeal tissues of the baboon. Laryngoscope, $93: 1607-1611,1983$. 